\title{
PENGARUH MOTIVASI DAN LINGKUNGAN KERJA TERHADAP KINERJA PEGAWAI SATUAN POLISI PAMONG PRAJA KECAMATAN SENEN
}

\author{
Rismayanda Simbolon 1) \\ 1) Mahasiswa Program Studi Manajemen FE UNKRIS \\ Hery Wihasnanto ${ }^{2)}$ \\ 2) Dosen Program Studi Manajemen FE UNKRIS \\ Alamat: Kampus UNKRIS, Jatiwaringin Jakarta Timur \\ Email : herywihasnanto@unkris.ac.id
}

\begin{abstract}
To determine the Effect of Motivation and Work Environment on Employee Performance of Satuan Polisi Pamong Praja Kecamatan Senen. The method used is a descriptive method with an associative approach. The sampling technique used is nonprobability sampling using a saturated sampling technique method with a sample of 85 Satpol PP Kecamatan Senen. Data analysis used simultaneously and partially linear regression analysis. The results showed that motivation and work environment have an influence either partially or simultaneously on the performance of Satuan Polisi Pamong Praja Kecamatan Senen.
\end{abstract}

\section{Keywords: Motivation, work environment and employee performance}

\section{PENDAHULUAN}

Pada saat sekarang ini bangsa Indonesia berada di tengah-tengah era globalisasi, seiring dengan berjalannya periode waktu terjadinya berbagai tuntutan perubahan secara radikal di seluruh bidang yang mengarah ke berbagai aspek kehidupan masyarakat, berbangsa dan bernegara. Seluruh masyarakat atau setiap warga negara menuntut pemerintah yang ada sekarang ini untuk melakukan perubahan secara menyeluruh, yaitu ke arah pemerintah yang mencerminkan good government, sehingga pemerintahan di masa yang akan datang dapat diarahkan akan lebih responsif terhadap kepentingan rakyat banyak atau masyarakat Indonesia, dengan mengimplementasikannya secara kongrit/nyata dalam pelaksanaan pemerintahan sehari-hari.

Tuntutan terhadap peningkatan pelayanan kepada masyarakat, mengharuskan aparatur pemerintah untuk lebih peka dan tanggap dalam merespon keinginan masyarakat. Tuntutan sikap profesionalisme aparatur pemerintah dalam melaksanakan tugas dan tanggung jawabnya adalah sejalan dengan semakin meningkatnya tuntutan masyarakat yang semakin memahami akan haknya sebagai warga negara, dan perkembangan ilmu dan teknologi maupun lingkungan. Apabila mutu pelayanan yang diberikan oleh aparatur pemerintah kurang memenuhi harapan masyarakt dan berjalan terus menerus, maka keadaan ini sedikit lebih banyak akan mempengaruhi tingkat kepercayaan masyarakat terhadap peran pemerintah sebagai penyelenggara negara menjadi suatu keharusan yang tidak mungkin ditawar-tawar.

Dengan adanya fenomena dan berbagai tuntutan tersebut, sebaiknya pemerintah segera melakukan evaluasi dan perbaikan di segala bidang yang berdampak pada peningkatan kinerja 
aparatur pemerintah di dalam menjalankan roda pembangunan di berbagai aspek kehidupan masyarkat.

Berdasarkan kondisi seperti, telah diterbitkan Peraturan Pemerintah Nomor 06 Tahun 2010 tentang Polisi Pamong Praja, khususnya pada pasal 2 ayat (1) menyebutkan bahwa pembentukan Sat Pol PP dimaksudkan untuk membantu kepala daerah dalam menegakkan Perda dan penyelengaraan ketertiban umum dan ketentraman masyarakat di setiap provinsi dan kabupaten/kota. Dan pada pasal 3 ayat (1) disebutkan bahwa Sat Pol PP merupakan bagian perangkat daerah di bidang penegakan Perda, ketertiban umum dan ketentraman masyarakat.

Diberikannya kewenangan kepada Sat Pol PP untuk memelihara keamanan dan ketertiban masyarakat bukanlah tanpa alasan, tapi didasari oleh kewajiban pemerintah untuk memberikan rasa aman dan tertib kepada warganya. Hal ini didukung oleh dasar pijakan yuridis yang jelas, sebagaimana dinyatakan dalam Undang-Undang Nomor 32 Tahun 2004 tentang Pemerintah Daerah, khususnya Pasal 13 dan 14 pada huruf c, yang menyebutkan: urusan wajib yang menjadi kewenangan Pemerintah Daerah meliputi penyelenggaraan ketertiban umum dan ketentraman masyarakat.

Demikian pula Pasal 148 dan Pasal 149 Undang-Undang Nomor 32 Tahun 2004 Pemerintah Daerah yang mengamanatkan dibentuknya Satuan Polisi Pamong Praja untuk membantu Kepala Daerah dalam menegakkan Peraturan Daerah dan penyelenggaran ketertiban umum serta ketentraman masyarakat. Satuan Polisi Pamong Praja, disingkat Satpol PP, adalah perangkat Pemerintah Daerah dalam memelihara ketentraman dan ketertiban umum serta menegakkan Peraturan Daerah. Organisasi dan tata kerja Satuan Polisi Pamong Praja ditetapkan dengan Peraturan Daerah.
Dalam berbagai kesempatan, Menteri Dalam Negeri Republik Indonesia (2010), menyampaikan bahwa belakangan ini gerak langkah Satuan Polisi Pamong Praja tidak pernah luput dari perhatian publik, mengingat segala aktivitasnya dengan mudah diketahui melalui pemberitaan di mass media, baik cetak maupun elektronik. Sayangnya citra yang terbentuk didalam benak masyarakat atas segala kegiatan aparat Sat Pol PP sangat jauh dari sosok ideal, yang sejatinya menggambarkan aparatur pemerintah daerah yang dalam melaksanakan tugasnya menjunjung tinggi norma hukum, norma agama, Hak Asasi Manusia dan norma-norma sosial lainnya yang hidup dan berkembang di masyarakat.

Dalam menghadapi seperti kondisi ini, Sat Pol PP harus dapat mengambil sikap yang tepat dan bijaksana, sesuai dengan paradigma baru Polisi Pamong Praja yaitu menjadi aparat yang ramah, bersahabat, dapat menciptakan suasana batin dan nuansa kesejukan bagi masyarakat, namun tetap tegas dalam bertindak demi tegaknya peraturan yang berlaku. Oleh sebab itu, dalam rangka mengantisipasi perkembangan dan dinamika masyarakat seiring dengan tuntutan zaman yang kompetitif dan ekonomi daerah, setiap personil Sat Pol PP dituntut untuk semakin meningkatkan kinerjanya.

Dengan melihat pada kewenangan yang diberikan kepada Sat Pol PP, maka sangat dibutuhkan pegawai Sat Pol PP yang memiliki ketrampilan, pengetahuan, keahlian dan kemampuan untuk menghadapi berbagai maslah dan tantangan yang seringkali mencul di setiap operasi penertiban di lapangan. Untuk itu dibutuhkan semangat motivasi yang tinggi bagi pegawai Sat Pol PP yang dapat mengarah kepada semua anggota untuk bersikap profesionalisme.

Kinerja pegawai Sat Pol PP yang tinggi diharapkan dapat membantu 
pemerintah daerah dalam menjaga keamanan dan ketentraman bagi masyarakat banyak.

Kaulitas pelaksanaan tugas yang dilakukan dengan semangat kerjasama dan penuh tanggung jawab sesuai lingkungan kerja dan organisasnya, akan lebih dapat menjaga keamanan dan ketentraman lingkungan masyarakat. Dalam rangka meningkatkan kinerja, persoalan motivasi kerja juga tidak bisa diabaiakan, ini dapat dirasakan apabila motivasi kerja dari pegawai Sat Pol PP menurun, maka akan berakibat terjadinya penanganan keamanan yang kurang optimal dan ketentraman masyarakat menjadi resah.

Motivasi adalah "keinginan dalam diri seseorang yang menyebabkan orang tersebut bertindak". Orang biasanya bertindak karena suatu alasan untuk mencapai tujuan. Jadi motivasi adalah sebuah dorongan yang diatur oleh sebuah tujuan dan jarang muncul dalam kekosongan. Motivasi merupakan kebutuhan, keinginan, hasrat, dan dorongan yang diinginkan seseorang ".

Faktor lain yang dapat meningkat kinerja dalam segala persoalan salah satunya adalah lingkungan kerja. lingkungan kerja menjadi sangat penting untuk menjadi bahan evaluasi dan menjadi perhatian dalam rangka menumbuhkan semangat kerja para bawahan, yang pada gilirannya akan berdampak pada kinerja dalam pelaksanaan tugas masing-masing.

Seiring dengan berjalannya waktu, bila ditelaah dari sisi kependudukan, maka masyarakat dalam suatu wilayah selalu tumbuh dan berkembang. Hal ini mengakibatkan perlu adanya pengaturan yang lebih baik dari sisi pemerintah untuk dapat mengantisipasi segala macam tantangan yang bermuara pada terancamnya ketertiban umum dan ketenteraman masyarakat di wilayah kerjanya. Berdasarkan hal tersebut, Menteri Dalam Negeri pada tanggal 3
Maret 1950 mengeluarkan Surat Keputusan Nomor UR 32/2/21 tentang Perubahan Nama Detasemen Polisi Pamong Praja Menjadi Satuan Polisi Pamong Praja. Surat Keputusan tersebut menjadi dasar peringatan Hari Jadi Satuan Polisi Pamong Praja yang diperingati setiap tanggal 3 Maret.

Tujuan penelitian ini adalah untuk mengetahui pengaruh motivasi dan lingkungan kerja terhadap kinerja Satuan Polisi Pamong Praja Kecamatan Senen.

\section{LANDASAN TEORI}

\section{Motivasi}

Motivasi merupakan suatu perubahan yang terjadi pada diri seseorang yang muncul gejala perasaan, kegelisahaan, kejiwaan, hingga emosi yang terdorong pada suatu individu dalam melakukan suatu tindakan karena suatu kebutuhan, keinginan, dan tujuan.

Menurut Uno (2011), Motivasi dapat diartikan "sebagai suatu dorongan internal dan eksternal dalam diri individu yang diindikasikan dengan adanya keinginan, minat, dan hasrat, dorongan juga kebutuhan; cita-cita dan harapan; serta penghargaan dan penghormatan". Sedangkan menurut Mangkunegara (2017), Motivasi merupakan "suatu rangsangan, dorongan, ataupun pembangun yang terdapat pada seseorang atau sekelompok masyarakat dalam berbuat dan bekerja secara optimal dalam melakukan sesuatu yang sudah direncanakan dalam mencapai tujuan tertentu yang sudah ditetapkan". Kemudian Hasibuan (2017) Motivasi berasal dari kata 'movere' yang berarti "dorongan atau pemberian daya penggerak yang dapat memunculkan gairah dan semangat tindakan individu agar mereka dapat bekerjasama, kerja efektif, dan terintegrasi dengan segala daya upayanya dalam mencapai kepuasannya". Menurut Flippo (2013), Motivasi merupakan "suatu keahlian 
yang dapat mengarahkan suatu individu atau kelompok agar dapat melakukan suatu tindakan yang optimal, sehingga individu atau kelompok tersebut dapat mencapai tujuan yang diinginkannya".

Kesimpulan dari pengertian motivasi menurut para ahli mengatakan bahwa motivasi merupakan suatu dorongan untuk melakukan suatu tindakan baik positif maupun negatif.

Menurut Mangkunegara (2017) terdapat 5 teori motivasi yang sering digunakan sebagai berikut: 1). "Teori Hierarki Maslow; Teori Hierarki dikemukakan oleh Abraham Maslow, seorang psikologi di tahun 1943. Dalam teori ini dikatakan bahwa tingkatan kebutuhan hidup manusia didasarkan pada 5 jenis, mulai dari kebutuhan mendasar hingga kebutuhan yang paling tinggi. Tingkatan hierarki yang dimaksud adalah sebagai berikut: a). Kebutuhan Fisiologis. Kebutuhan hidup manusia yang paling dasar, seperti kebutuhan terhadap makanan, minuman, air, udara, pakaian, tempat tinggal dan kebutuhan untuk bertahan hidup. b). Kebutuhan Keamanan. Kebutuhan hidup manusia untuk memperoleh rasa aman dari kekerasan, baik secara fisik maupun psikis. Misalnya, lingkungan tempat tinggal yang bebas polusi, perlindungan keselamatan dari bahaya dan ancaman dalam hidupnya. c). Kebutuhan Sosial. Sesuai dengan sifat manusia sebagai makhluk sosial, yang membutuhkan orang lain dalam menjalankan hidupnya. Kebutuhan ini mengisyaratkan manusia untuk memiliki rasa mencintai dan dicintai. d). Kebutuhan Penghargaan. Kebutuhan yang berkaitan dengan fisiologis, keamanan dan sosial. Kebutuhan itu menjadikan orang tersebut berharap diakui oleh orang lain, memiliki reputasi dan rasa percaya diri serta dihargai oleh orang lain. e). Kebutuhan Aktualisasi diri. Kebutuhan yang paling tinggi dalam hidup manusia menurut Maslow, yaitu kebutuhan manusia untuk dapat memenuhi ambisi pribadinya. 2). Teori ERG Alderfer; Teori ERG Alderfer atau biasa dikenal dengan ERG saja dikemukakan oleh Aldefer yang diambil dari bentuk persamaan $\mathrm{E}=$ Existence yang berarti eksistensi kebutuhan, seperti fisiologis dan materialistis, $\mathrm{R}=$ Relatedness yang menyatakan hubungan dengan pihak lainnya, serta $\mathrm{G}=$ Growth yang diartikan sebagai kebutuhan tumbuh untuk mencapai potensi diri yang maksimal. 3). Teori Kebutuhan McClelland; David McClelland merupakan seorang psikolog yang mengemukakan pendapatnya mengenai teori dalam motivasi yang dibagi kedalam 3 jenis kebutuhan, yaitu kebutuhan prestasi, kebutuhan afiliasi dan kebutuhan akan kekuasaan. 4). Teori Motivasi Hygiene Herzberg; Teori Herzberg sering disebut juga sebagai teori dua faktor yang berbeda, yakni tingkat kepuasan dan ketidakpuasan dalam bekerja atau disebut juga dengan teori M-H. a). Kepuasan bekerja, yaitu faktor yang berhubungan dengan pengakuan, prestasi, tanggung jawab yang memberikan kepuasan positif bagi karyawan. b). Ketidakpuasan bekerja, yaitu faktor yang berhubungan dengan kondisi lingkungan kerja, hubungan antar individu, keamanan bekerja maupun gaji yang memberikan rasa tidak puas bagi karyawannya. 5). Teori Harapan Vroom; Victor Vroom yang merupakan seorang profesor di Kanada mengungkapkan teori motivasi dalam bukunya "Work and Motivation" yang berbunyi bahwa seseorang akan melakukan suatu tindakan karena mengharapkan hasil atau imbalan. Konsep teori harapan Vroom adalah sebagai berikut: a). Harapan (Expectancy), yaitu tingkat kepercayaan seseorang bahwa suatu usaha akan menghasilkan kinerja tertentu. b). Instrumentally, yaitu tingkat kepercayaan seseorang bahwa suatu 
kinerja yang dilakukan bisa mendapatkan hasil tertentu. c). Valensi (Valence), yaitu berkaitan dengan nilai positif dan negatif dari hasil yang telah dicapai”.

Ada banyak faktor yang dapat menimbulkan motivasi dalam diri seseorang. Motivasi sebagai psikologis dalam diri seseorang dipengaruhi oleh beberapa faktor, baik yang bersifat internal maupun eksternal (Sutrisno, 2016): 1). "Faktor Eksternal (berasal dari luar diri karyawan) yang dapat mempengaruhi motivasitersebut mencakup antara lain: a). Lingkungan kerja yang menyenangkan. b). Kompensasi yang memadai. c). Supervisi yang baik. d). Adanya jaminan pekerjaan. e). Status dan tanggung jawab. f). Peraturan yang fleksibel. 2). Faktor internal (berasal dari dalam diri karyawan) yang mempengaruhi pemberian motivasi pada diri seseorang, antara lain: a). Keinginan untuk dapat hidup. b). Keinginan untuk dapat memiliki. c). Keinginan untuk memperoleh penghargaan. d). Keinginan untuk memperoleh pengakuan. e). Keinginan untuk berkuasa".

Tujuan motivasi memegang peranan yang sangat penting dalam sebuah organisasi. Dengan adanya motivasi kerja, di prediksi akan menambah energi pada sebuah pekerjaan. Menurut Hasibuan (2017), Ada beberapa tujuan pemberian motivasi yaitu: 1). "Mendorong gairah dan semangat kerja karyawan. 2). Meningkatkan moral dan kepuasan kerja karyawan. 3). Meningkatkan produktivitas kerja karyawan. 4). Mempertahankan loyalitas dan kestabilan karyawan. 5). Meningkatkan kedisiplinan dan menurunkan tingkat absensi karyawan. 6). Mengefektifkan pengadaan karyawan. 7). Menciptakan suasana dan hubungan kerja yang baik. 8). Meningkatkan kreativitas dan partisipasi karyawan. 9). Meningkatkan tingkat kesejahteraan karyawan. 10). Mempertinggi rasa tangung jawab karyawan".

Indikator motivasi kerja dimaksudkan untuk dapat mengukur sejauh mana karyawan bekerja sesuai dengan tuntutan sebagai karyawan. Menurut Uno (2011) ada dua dimensi dan indikator motivasi kerja, yaitu antara lain: 1). "Motivasi Internal Indikator: a). Tanggungjawab karyawan dalam melaksanakan tugas. b). Melaksanakan tugas dengan target yang jelas. c). Ada umpan balik atas hasil pekerjaannya. d). Memiliki tujuan yang jelas dan menentang. e). Memiliki perasaan senang dalam bekerja. f). Selalu berusaha untuk mengungguli orang lain. g). Diutamakan prestasi dari apa yang dikerjakannya. 2). Motivasi Eksternal Indikator: a). Selalu berusaha untuk memenuhi kebutuhan hidup dan kebutuhan kerjanya. b). Senang memperoleh pujian dari apa yang dikerjakannya. c). Bekerja dengan harapan ingin memperoleh insentif. d). Bekerja dengan harapan ingin memperoleh perhatian dari teman dan atasan".

\section{Lingkungan Kerja}

Lingkungan kerja adalah kehidupan sosial, psikologi, dan fisik dalam perusahaan yang berpengaruh terhadap pekerja dalam melaksanakan tugasnya. Kehidupan manusia tidak terlepas dari berbagai keadaan lingkungan sekitarnya, antara manusia dan lingkungan terdapat hubungan yang sangat erat. Dalam hal ini, manusia akan selalu berusaha untuk beradaptasi dengan berbagai keadaan lingkungan sekitarnya.

Menurut Sedarmayati (2017) lingkungan kerja "merupakan keseluruhan alat perkakas dan bahan yang dihadapi, lingkungan sekitarnya dimana seseorang bekerja, metode kerjanya, serta pengaturan kerjanya baik sebagai perseorangan maupun sebagai 
kelompok". Sedangkan menurut Afandi (2018) adalah "sesuatu yang ada dilingkungan para pekerja yang dapat mempengaruhi dirinya dalam menjalankan tugas seperti temperature, kelembaban, pentilasi, penerangan, kegaduhan, kebersihan tempat kerja, dan memadai tidaknya alat-alat perlengkapan kerja”. Menurut Siagian (2014) mengemukakan bahwa lingkungan kerja adalah "lingkungan dimana karyawan melakukan pekerjaannya sehari-hari”.

Dari beberapa pendapat di atas dapat disimpulkan bahwa lingkungan kerja merupakan segala sesuatu yang ada disekitar karyawan pada saat bekerja, baik berbentuk fisik atau non fisik, langsung atau tidak langsung, yang dapat mempengaruhi dirinya dan pekerjaannya saat bekerja.

Lingkungan kerja didalam perusahaan/instansi sangat penting diperhatikan oleh pimpinan karena lingkungan kerja yang baik mempunyai pengaruh terhadap efektivitas yang bekerja dalam perusahaan. Di dalam usaha untuk membuat perencanaan lingkungan kerja maka perlu mengkaji dan menentukan aspek-aspek pembentuk lingkungan kerja itu sendiri.

$$
\text { Menurut Siagian }
$$

menyatakan bahwa secara garis besar, lingkungan kerja terdapat dua jenis yaitu: 1). "Lingkungan Kerja Fisik; Lingkungan kerja fisik adalah semua keadaan berbentuk fisik yang terdapat disekitar tempat kerja dan dapat mempengaruhi karyawan. Ada beberapa kondisi fisik dari tempat kerja yang baik yaitu: a). Bangunan tempat kerja disamping menarik untuk dipandang juga dibangun dengan pertimbangan keselamatan kerja. b). Tersedianya peralatan kerja yang memadai. c). Tersedianya tempat istirahat untuk melepas lelah, seperti kafetaria baik dalam lingkungan perusahaan atau sekitarnya yang mudah dicapai karyawan. d). Tersedianya tempati badah keagamaan seperti masjid dan musholla untuk karyawan. e). Tersedianya sarana angkutan, baik yang diperuntukkan karyawan maupun angkutan umum yang nyaman, murah dan mudah di peroleh. 2). Lingkungan Kerja Non Fisik; Lingkungan kerja non fisik adalah lingkungan kerja yang menyenangkan dalam arti terciptanya hubungan kerja yang harmonis antara karyawan dan atasan, karena pada hakekatnya manusia dalam bekerja tidak hanya mencari uang saja, akan tetapi bekerja merupakan bentuk aktivitas yang bertujuan untuk mendapatkan kepuasan".

Beberapa indikator lingkungan kerja menurut Mangkunegara (2017), yaitu: 1). "Penerangan / cahaya di tempat kerja; Cahaya lampu sangat besar manfaatnya bagi karyawan guna mendapat keselamatan dan kelancaran kerja, karena jika cahaya lampu yang tidak memadai akan berpengaruh terhadap keterampilan karyawan yang dalam melaksanakan tugas-tugasnya banyak mengalami kesalahan yang pada akhirnya pengerjaannya kurang efisien sehingga tujuan perusahaan sulit untuk dicapai. 2). Temperatur / suhu udara di tempat kerja; Setiap anggota tubuh manusia mempunyai temperatur yang berbeda. Manusia selalu mempertahankan tubuhnya dalam keadaan normal, dengan suatu sistem tubuh yang sempurna sehingga dapat menyesuaikan diri dengan perubahan yang terjadi di luar tubuh. Tetapi kemampuan untuk menyesuaikan diri tersebut ada batasnya. Manusia dapat menyesuaikan dirinya dengan temperatur luar jika perubahan temperatur luar tubuh tidak lebih dari 20\% untuk kondisi panas dan $35 \%$ untuk kondisi dingin, dari keadaan normal tubuh. 3). Kelembaban di tempat kerja; Kelembaban adalah banyaknya air yang terkandung dalam udara, biasanya dinyatakan dalam persentase. Kelembaban ini berhubungan atau 
dipengaruhi oleh temperatur udara. Jika keadaan dengan temperatur udara sangat panas dan kelembaban tinggi, akan menimbulkan pengurangan panas dari tubuh secara besar, karena sistem. Selain itu, semakin cepatnya denyut jantung diakibatkan aktifnya peredaran darah untuk memenuhi kebutuhan oksigen, dan tubuh manusia akan selalu berusaha untuk mencapai keseimbangan antara panas tubuh dengan suhu disekitarnya. 4). Sirkulasi udara di tempat kerja; Udara disekitar dikatakan kotor apabila kadar oksigen dalam udara tersebut telah berkurang dan telah bercampur dengan gas atau bau-bauan yang berbahaya bagi kesehatan tubuh. Oksigen merupakan gas yang dibutuhkan oleh makhluk hidup untuk menjaga kelangsungan hidup, yaitu proses metabolisme. Dengan cukupnya oksigen di sekitar tempat kerja, maka akan memberikan kesejukan dan kesegaran pada jasmani, sumber utamanya adalah tanaman di sekitar tempat kerja, karena tanaman merupakan penghasil oksigen yang dibutuhkan oleh manusia. Dengan terciptanya rasa sejuk dan segar selama bekerja akan membantu mempercepat pemulihan tubuh akibat lelah setelah bekerja. 5). Kebisingan di tempat kerja; Kebisingan merupakan suatu bunyi yang tidak dikehendaki oleh telinga, karena jika dalam jangka panjang bunyi tersebut dapat mengganggu ketenangan dalam bekerja, merusak pendengaran, dan menimbulkan kesalahan dalam berkomunikasi. Bahkan menurut penelitian, kebisingan serius dapat menyebabkan kematian. Kriteria pekerjaan membutuhkan konsentrasi, maka suara bising hendaknya dihindarkan agar pelaksanaan pekerjaan dapat dilakukan dengan efisien. 6). Hubungan Karyawan; Dalam hubungan karyawan ini terdapat dua hubungan yaitu hubungan sebagai individu dan hubungan sebagai kelompok. Hubungan sebagai individu, motivasi yang diperoleh seorang karyawan datangnya dari rekan-rekan sekerja maupun atasan. Menjadi sebuah motivasi, jika hubungan karyawan dengan rekan sekerja maupun atasannya berlangsung harmonis. Begitu juga dengan sebaliknya, jika hubungan di antara mereka tidak harmonis, maka akan mengakibatkan kurangnya atau tidak ada motivasi di dalam diri karyawan yang bekerja. 7). Dekorasi di tempat kerja; Dekorasi ada hubungannya dengan tata warna yang baik, karena dekorasi tidak hanya berkaitan dengan hiasan ruang kerja saja, akan tetapi berkaitan juga dengan cara mengatur tata letak, tata warna, perlengkapan, dan lainnya untuk bekerja. 8). Musik di tempat kerja; Menurut para pakar, musik yang nadanya lembut sesuai dengan suasana, waktu dan tempat dapat membangkitkan dan merangsang karyawan untuk bekerja. Oleh karena itu, lagu-lagu perlu dipilih dengan selektif untuk dikumandangkan di tempat kerja. 9). Keamanan di tempat kerja; Guna menjaga tempat dan kondisi lingkungan kerja tetap dalam keadaan aman, maka perlu diperhatikan adanya keamanan dalam bekerja. Oleh karena itu faktor kemanan perlu diwujudkkan keberadaannya. Salah satu upaya untuk menjaga keamanan di tempat kerja adalah dengan memanfaatkan tenaga Satuan Petugas Keamanan (SATPAM)".

\section{Kinerja}

Kinerja adalah hasil kerja secara kualitas dan kuantitas yang dicapai oleh seorang pegawai dalam melaksanakan fungsinya sesuai dengan tanggung jawab yang diberikan kepadanya. Menurut Bernardin dan Russel, (2013) memberikan pengertian atau kinerja sebagai berikut: "performance is defined as the record of outcomes produced on a specified job function or activity during time period". Prestasi atau kinerja adalah "catatan tentang hasil-hasil yang 
diperoleh dari fungsi-fungsi pekerjaan tertentu atau kegiatan selama kurun waktu tertentu". Sedangkan menurut Gibson, (2010) Job performance adalah "hasil dari pekerjaan yang terkait dengan tujuan organisasi, efisiensi dan kinerja kefektifan kinerja lainnya".

Selanjutnya Ilyas (2012), Kinerja adalah "penampilan hasil kerja personil maupun dalam suatu organisasi". Penampilan hasil karya tidak terbatas kepada personil yang memangku jabatan fungsional maupun struktural tetapi juga kepada keseluruhan jajaran personil di dalam organisasi. Menurut As'ad (2013), kinerja adalah "hasil yang dicapai seseorang menurut ukuran yang berlaku untuk pekerjaan yang bersangkutan".

Kemudian menurut Simanjuntak (2011), Mengemukakan kinerja adalah "tingkat pencapaian hasil atas pelaksanaan tugas tertentu". Kinerja perusahaan adalah tingkat pencapaian hasil dalam rangka mewujudkan tujuan perusahaan. Manajemen kinerja adalah keseluruhan kegiatan yang dilakukan untuk meningkatkan kinerja perusahaan atau organisasi, termasuk kinerja masingmasing individu dan kelompok kerja di perusahaan tersebut.

Berdasarkan pendapat tersebut di atas, maka dapat disimpulkan bahwa kinerja merupakan hasil dari suatu yang telah dikerjakan dalam organisasi sesuai tanggung jawab dan wewenang yang telah diberikan kepada individu atau kelompok kerja guna mencapai tujuan organisasi sesuai dengan nilai dan norma yang ada.

Bernardin dan Russel (2010) mengajukan enam kinerja primer yang dapat digunakan untuk mengukur kinerja, yaitu: 1). "Quality. Merupakan tingkat sejauh mana proses atau hasil pelaksanaan kegiatan mendekati kesempurnaanyang diharapkan. 2). Quantity. Merupakan jumlah yang dihasilkan. 3). Timeliness. Merupakan sejauh mana suatu kegiatan diselesaikan pada waktu yang dikehendaki, dengan memperhatikan output lain serta waktu yang tersedia untuk kegiatan orang lain. 4). Cost effectiveness. Merupakan tingkat sejauh mana penggunaan sumber daya organisasi dimaksimalkan untuk mencapai hasil tertinggi atau pengurangan kerugian dari setiap unit penggunaan sumber daya. 5). Need for supervision. Merupakan tingkat sejauh mana seorang pekerja dapat melaksanakan suatu fungsi pekerjaan tanpa memerlukan pengawasan seorang supervisor untuk mencegah tindakan yang kurang diinginkan. 6). Interpersonal impact. Merupakan tingkat sejauh mana pegawai memelihara harga diri, nama baik, dan kerja sama diantara rekan kerja dan bawahan".

Menurut Stoner dalam Sutrisno (2016), mengemukakan adanya tiga cara untuk meningkatkan kinerja karawan, yaitu: 1). "Diskriminasi; Seorang pimpinan harus mampu membedakan secara objektif antara mereka yang dapat memberi sumbangan berarti dalam pencapaian tujuan organisasi dengan mereka yang tidak.dalm konteks penilaian kerja memang harus ada perbedaan antara karyawan yang berprestasi dengan karyawan yang tidak berprestasi. Oleh karena itu, dapat dibuat keputusan yang adil dalam berbagai bidang, misalnya pengembangan SDM, penggajian dan sebagainya. 2). Pengharapan; Dengan memerhatikan bidang tersebut diharakan bisa meningkatkan kinerja karyawan. Karyawan yang meiliki kinerja tinggi mengharapkan pengakuan dalam bentuk berbagai pengharapan yang diterimanya dari organisasi. Untuk mempertinggi motivasi dan kinerja, mereka yang tampil mengesankan dalam bekerja harus dididentifikasi sedemikian rupa sehingga penghargaan memang jatuh pada tangan yang memang berhak. Pengembangan bagi yang bekerja dibawah standar, skema untuk mereka adalah mengikuti 
program pelatihan dan pengembangan. Sedangkan yang diatas standar, misalnya dapat dipromosikan kepada jabatan yang lebih tinggi. Berdasarkan hasil laporan manajemen, bagaimanapun bentuk kebijakan organisasi dapat tejamin keadilan dan kejujurannya. Untuk itu diperlukan suatu tanggung jawab yang penuh pada manajer yang membawahinya. 3). Komunikasi; Para pimpinan bertanggung jawab untuk mengevaluasi kinerja para karyawan dan secara akurat mengomunikasikan penilaian yang dilakukannya. Untuk dapat melakukan sacara akurat, para pimpinan harus mengetahui kekurangan dan masalah apa saja yang dihadapi para karyawan dan bagaimana cara mengatasinya. Disamping itu, para pimpinan juga harus mengetahui program pelatihan dan pengembangan apa saja yang dibutuhkan. Untuk memastikannya, para manajer perlu berkomunikasi secara intens dengan karyawan".

Menurut Robbins, (2015), Indikator untuk mengukur kinerja karyawan secara individu ada lima indikator yaitu: 1). "Kualitas, kualitas kerja diukur dari persepsi karyawan terhadap kualitas pekerjaan yang dihasilkan serta kesempurnaan tugas terhadap keterampilan dan kemampuan karyawan. 2). Kuantitas merupakan jumlah yang dihasilkan dinyatakan dalam istilah seperti jumlah unit, jumlah siklus aktivitas yang diselesaikan. 3). Ketepatan waktu, merupakan tingkat aktivitas diselesaikan pada awal waktu yang dinyatakan, dilihat dari sudut koordinasi dengan hasil output serta memaksimalkan waktu yang tersedia untuk aktivitas lain. 4). Efektivitas merupakan tingkat penggunaan sumber daya organisasi "tenaga, uang teknologi, bahan baku" dimaksimalkan dengamn maksud menaikkan hasil dari setiap unit dalam penggunaan sumber daya. 5). Kemandirian, merupakan tingkat seorang karyawan yang nantinya akan dapat menjalankan fungsi kerjanya Komitmen kerja. Merupakan suatu tingkat dimana karyawan mempunyai komitmen kerja dengan instansi dan tanggung jawab karyawan terhadap kantor".

\section{METODE PENELITIAN}

Metode yang digunakan adalah metode deskriptif dengan pendekatan asosiatif. Teknik sampling yang digunakan adalah non probability sampling menggunakan metode teknik sampling jenuh dengan sampel sebanyak 85 Satpol PP Kecamatan Senen. Analisis data menggunakan analisis regresi linear berganda dan sederhana.

\section{HASIL PENELITIAN DAN PEMBAHASAN}

\section{Hasil Penelitian}

\section{Uji validitas}

Pengujian validitas ini dilakukan untuk menguji apakah tiap butir pernyataan telah mewakili indikator yang akan diteliti, dengan menggunakan $r$ tabel didapat nilai $\mathrm{r}=0,213$ yang diperoleh dari $\mathrm{N}=85$, alpha 5\%. Jadi, apabila korelasi antara butir-butir item pernyataan dengan skor total kurang dari 0,213 , maka butiran dalam instrumen tersebut dapat dikatakan tidak valid. Uji validitas dilakukan dengan melihat korelasi antara skor masing-masing item pernyataan dengan skor total. (Riduwan dan Sunarto, 2013).

Dari perhitungan koefisien korelasi skor tiap butir pernyataan dari 85 responden tentang instrument motivasi, dengan jumlah 11 pernyataan; instrumen lingkungan 9 pernyataan dan instrumen kinerja pegawai 10 pernyataan dengan total skor setiap responden diperoleh hasil $r$ hitung lebih besar dari $r$ tabel 0,213 . 


\section{Uji reliabilitas}

uji reliabilitas untuk mengetahui sejauh mana hasil pengukurannya dapat diandalkan dan konsisten. Pada tabel hasil pengujian berikut diketahui bahwa semua variabel mempunyai alpha di atas 0.60 yang berarti bahwa semua variabel dalam penelitian ini dapat diandalkan. (Sugiyono, 2018).

Tabel 1: Hasil Uji Reliabilitas

\begin{tabular}{lccc}
\hline \multicolumn{1}{c}{ Variabel } & $\begin{array}{c}\text { Cronbach } \\
\text { Alpha }\end{array}$ & $\begin{array}{c}\text { Nilai kritis } \\
(\boldsymbol{\alpha})=\mathbf{5 \%}\end{array}$ & Keterangan \\
\hline Motivasi & 0.859 & 0.600 & Reliabel \\
Lingkungan Kerja & 0.824 & 0.600 & Reliabel \\
Kinerja Pegawai & 0.794 & 0.600 & Reliabel \\
\hline
\end{tabular}

Sumber: Data Primer, diolah tahun 2021

Berdasarkan Tabel 1, angka-angka reliabilitas cronbach alpha tersebut tampak bahwa seluruh pernyataan yang ada membentuk ukuran yang reliabel dari

\section{Analisis Regresi Linear Berganda}

Tabel 2: Pengaruh Motivasi dan Lingkungan Kerja Terhadap Kinerja Pegawai Satpol PP Kec. Senen

\begin{tabular}{lccccc}
\hline & \multicolumn{5}{c}{ Parameter } \\
\cline { 2 - 6 } Variabel & Mult. $\mathbf{R}$ & $\begin{array}{c}\text { R } \\
\text { Square }\end{array}$ & Konstanta & $\begin{array}{c}\text { Koefisien } \\
\text { Regresi }\end{array}$ & Sig. \\
\hline Motivasi & 0,900 & 0,810 & 15,923 & 0,536 & 0,000 \\
Ling_Kerja & & & & 0,199 & 0,021 \\
\hline Pengujian Signifikan & & & 0,000 \\
\hline F hitung = 175,076 &
\end{tabular}

Keterangan: Variabel Kinerja

Sumber : data diolah 2021

Tabel 2, nilai $\mathrm{F}$ hitung $=175,076$ atau signifikansi probabiliti 0.000 lebih kecil dari 0,05, maka Ho tolak, Ha terima, artinya ada pengaruh yang signifikan motivasi dan lingkungan kerja terhadap kinerja pegawai Satuan Polisi Pamong Praja Kecamatan Senen. Nilai korelasi (r) sebesar 0,900, artinya ada hubungan yang sangat kuat motivasi dan lingkungan kerja dengan kinerja pegawai Satuan Polisi Pamong Praja Kecamatan Senen. Nilai koefisien determinasi $\left(\mathrm{R}^{2}\right)$ sebesar 0.810, artinya motivasi dan lingkungan kerja secara bersama-sama memberikan kontribusi sebesar 81,0\% kepada kinerja pegawai Satuan Polisi mulai motivasi, lingkungan kerja, dan kinerja pegawai membentuk ukuran yang reliabel dari masing-masing variabel. 
Kecamatan Senen akan meningkat atau sebaliknya dengan asumsi lingkungan kerja tidak berubah. Koefisien lingkungan kerja sebesar 0,199, artinya jika ada peningkatan lingkungan kerja, maka kinerja pegawai Satuan Polisi Pamong Praja Kecamatan Senen, akan meningkat atau sebaliknya, dengan asumsi motivasi tidak berubah. Dengan demikian hipotesis pertama diterima.

\section{Analisis Regresi Linear Sederhana}

Tabel 3: Pengaruh Motivasi Terhadap Kinerja Pegawai Satpol PP Kec. Senen

\begin{tabular}{lcccccc}
\hline \multirow{2}{*}{ Variabel } & $\mathbf{R}$ & $\begin{array}{c}\mathbf{R} \\
\text { Square }\end{array}$ & $\begin{array}{c}\text { Kons } \\
\text { tanta }\end{array}$ & $\begin{array}{c}\text { Koefisien } \\
\text { Regresi }\end{array}$ & Sig & $\boldsymbol{\alpha}$ \\
\cline { 2 - 7 } & 0,893 & 0,797 & 17,766 & 0,665 & 0,000 & 0,05 \\
\hline Motivasi & & & & & \\
\hline Pengujian Signifikan & & & & \\
\hline t hitung = 18,073 & & & & \\
\hline $\begin{array}{l}\text { Keterangan: Variabel Kinerja } \\
\text { Sumber: data diolah 2021 }\end{array}$
\end{tabular}

Tabel 3, nilai korelasi (r) sebesar 0,893, artinya ada hubungan yang kuat antara motivasi dengan kinerja pegawai Satuan Polisi Pamong Praja Kecamatan Senen. Nilai koefisien determinasi $\left(\mathrm{R}^{2}\right)$ sebesar 0.797, artinya motivasi memberikan kontribusi sebesar 79,7\% kepada kinerja pegawai Satuan Polisi Pamong Praja Kecamatan Senen, sedangkan sisanya sebesar 10,3\% disumbangkan faktor lain yang tidak diteliti.

Persamaan Regresi $\mathrm{Y}=17,766+0,665$ $\left(\mathrm{X}_{1}\right)$
Motivasi berpengaruh positif dan signifikan pada tingkat nyata $99 \%$ terhadap kinerja pegawai Satuan Polisi Pamong Praja Kecamatan Senen. Koefisien motivasi sebesar 0,665, artinya jika ada peningkatan motivasi, maka kinerja pegawai Satuan Polisi Pamong Praja Kecamatan Senen akan meningkat.

Nilai $\mathrm{t}$ hitung $=18,073$ atau signifikansi probabiliti 0,000 lebih kecil dari 0,05, maka Ho tolak, Ha terima, artinya ada pengaruh signifikan motivasi terhadap kinerja pegawai Satuan Polisi Pamong Praja Kecamatan Senen. Dengan demikian hipotesis kedua diterima.

Tabel 4: Pengaruh Lingkungan Kerja Terhadap Kinerja Pegawai Satpol PP Kec. Senen

\begin{tabular}{lcccccc}
\hline & \multicolumn{6}{c}{ Parameter } \\
\cline { 2 - 6 } Variabel & $\mathbf{R}$ & $\begin{array}{c}\mathbf{R} \\
\text { Square }\end{array}$ & $\begin{array}{c}\text { Konst } \\
\text { anta }\end{array}$ & $\begin{array}{c}\text { Koefisien } \\
\text { Regresi }\end{array}$ & Sig & $\boldsymbol{\alpha}$ \\
\hline Ling_Kerja & 0,809 & 0,655 & 20,778 & 0,778 & 0,000 & 0.05 \\
\hline Pengujian Signifikan & & & & \\
\hline t hitung > t tabel = 12,551 & & & & \\
\hline Keterangan: Variabel Kinerja \\
Sumber : data diolah 2021
\end{tabular}

Tabel 4, nilai korelasi (r) sebesar 0,809 , artinya ada hubungan yang kuat antara lingkungsn kerja dengan kinerja pegawai Satuan Polisi Pamong Praja Kecamatan Senen pada tingkat hubungan yang sangat kuat. Nilai koefisien 
determinasi $\left(\mathrm{R}^{2}\right)$ sebesar 0.655 , artinya lingkungan kerja memberikan kontribusi sebesar $65,5 \%$ kepada kinerja pegawai Satuan Polisi Pamong Praja Kecamatan Senen, sedangkan sisanya sebesar $34,5 \%$ disumbangkan faktor lain yang tidak diteliti.

Persamaan Regresi $\mathrm{Y}=20,797+0,778$ $\left(\mathrm{X}_{2}\right)$

Lingkungan kerja berpengaruh positif dan signifikan pada tingkat nyata 99\% terhadap kinerja pegawai Satuan Polisi Pamong Praja Kecamatan Senen. Koefisien lingkungan kerja sebesar 0,778 , artinya jika ada perbaikan lingkungan kerja, maka kinerja pegawai Satuan Polisi Pamong Praja Kecamatan Senen akan meningkat.

Nilai $\mathrm{t}$ hitung $=12,551$ atau signifikansi probabiliti 0,000 lebih kecil dari 0,05, maka Ho tolak, Ha terima, artinya ada pengaruh signifikan lingkungan kerja terhadap kinerja pegawai Satuan Polisi Pamong Praja Kecamatan Senen. Dengan demikian hipotesis ketiga diterima.

\section{Pembahasan}

Pengaruh Motivasi dan Lingkungan Kerja Terhadap Kinerja Pegawai Satuan Polisi Pamong Praja Kecamatan Senen

Hasil analisis diketahui bahwa motivasi dan lingkungan kerja mendorong peningkatan kinerja pegawai Satuan Polisi Pamong Praja Kecamatan Senen. Hasil penelitian ini sama dengan hasil penelitian yang dilakukan oleh Arianto dan Kurniawan (2020) dan Heruwanto, et al, (2018), yaitu menganalisis pengaruh motivasi dan lingkungan kerja terhadap kinerja karyawan.

\section{Pengaruh Motivasi terhadap Kinerja Pegawai Satuan Polisi Pamong Praja Kecamatan Senen}

Hasil penelitian ini menunjukkan bahwa motivasi yang diberikan oleh atasan dapat mendorong peningkatan kinerja pegawai. Hal ini dikarenakan bahwa Sat Pol PP bertanggung jawab penuh dalam melaksanakan tugas dengan target yang jelas, adanya umpan balik hasil kerja Sat Pol PP, memiliki tujuan yang jelas dan menantang, memiliki perasaan senang dalam bertugas, berusahaan memberikan prestasi yang dikerjakannya, Sat Pol PP berusaha memenuhi kebutuhan hidupnya, senang mendapat pujian apa yang dikerjakannya, harapan mendapat insentif dan memperoleh perhatian dari atasan. Hasil penelitian ini sesuai dengan penelitian yang dilakukan oleh Arianto dan Kurniawan, (2020) dan Rusmawita (2016), yaitu menganalisis pengaruh motivasi terhadap kinerja karyawan.

\section{Pengaruh Lingkungan Kerja terhadap Kinerja Pegawai Satuan Polisi Pamong Praja Kecamatan Senen}

Hasil penelitian ini menunjukkan bahwa lingkungan kerja mendorong peningkatan kinerja pegawai. Hal ini dikarenakan bahwa perlengkapan dan penerangan di tempat kerja sudah memadai, temperatur ruangan disesuaikan dengan kondisi udara, kelembaban udara dapat mengganggu pekerjaan, sirkulasi udara sudah baik, bekerja dengan konsentrasi yang baik karena jauh dari kebisingan, terajlin hubungan yagn harnonis antara atasan dengan bawahan, ruang kerja ditata dengan baik, musik yanglembuat membuat nyaman dalam bekerja dan jaminan kemanan dalam menjalankan tugas. Hasil penelitian ini sejalan dengan penelitian yang dilakukan oleh Chanderson dan Suprastha (2020) dan Demus, et al, (2015), yaitu menganalisis 
pengaruh lingkungan kerja terhadap kinerja karyawan.

\section{KESIMPULAN DAN SARAN}

\section{Kesimpulan}

Berdasarkan hasil penelitian dan pembahasan yang telah dikemukakan sebelumnya maka dapat diambil kesimpulan adalah sebagai berikut : 1). Motivasi dan lingkungan kerja mendorong peningkatan kinerja pegawai Sat Pol PP Kecamatan Senen. 2). Motivasi mendorong peningkatan kinerja pegawai Sat Pol PP Kecamatan Senen. 3). Lingkungan kerja terhadap kinerja pegawai Satpol PP Kecamatan Senen.

\section{Saran}

Berdasarkan kesimpulan, saransaran yang dapat diberikan yaitu: 1). Motivasi pegawai Sat Pol PP Kecamatan Senen perlu ditingkatkan kembali agar, tujuan oganisasi berjalan lebih efektif dan efisien, sebab motivasi merupakan hal yang penting dalam peningkatan kinerja pegawai sehingga tujuan organisasi akan mudah tercapai. 2). Lingkungan kerja Sat Pol PP Kecamatan Senen perlu lihat kembali seperti lingkungan kerja fisik yaitu kondisi ruang kerja, penerangan, sirkulasi udara dan tata ruang agar tetap terjaga sehingga pegawai terasa lebih nyamam dalam bekerja. 3). Kinerja pegawai yang ada didalam organisasi dapat dibentuk melalui motivasi yang baik dan lingkungan kerja yang nyaman. Karena dengan kedua faktor tersebut dinilai dapat meningkatkan hasil kerja pegawai untuk mencapai tujuan organisasi. 4). Bagi penelitian selanjutnya diharapkan untuk menggunakan periode penelitian yang lebih panjang sehingga diharapkan dapat memperoleh hasil yang lebih dan diharapkan untuk dapat menambah variabel-variabel penelitian yang lebih berpengaruh terhadap kinerja pegawai, khsususnya mengenai kinerja Sat Pol PP.

\section{DAFTAR PUSTAKA}

Afandi, P. 2018. Manajemen Sumber Daya Manusia (Teori, Konsep dan Indikator). Riau: Zanafa Publishing.

Arianto, Nurmin dan Kurniawan, Hadi. 2020. "Pengaruh Motivasi dan Lingkungan Kerja Terhadap Kinerja Karyawan". Jurnal Ilmiah, Manajemen Sumber Daya Manusia Jenius. Vol. 3 No. 3, Mei 2020. Hal. 312-321.

As'ad, Mohammad. 2013. Psikologi Industri, Seri Ilmu Sumber Daya Manusia. Jakarta: Liberty.

Bernardin, H. J dan Russell, J. E. A. 2013. Human Resource Management, Sixth Edition. New York: McGrawHill

Chanderson, Lewis dan Suprastha, Nyoman. 2020. "Pengaruh Lingkungan Kerja dan Motivasi Terhadap Kinerja Karyawan Pada PT Sunrise Polybag”. Jurnal Manajerial dan Kewirausahaan, Volume II No. 1/2020. Hal. 122130.

Demus, Aditya W., Kindangen, Paulus dan Tielung, Maria V.J. 2015. "The Impact of Work Environment on Employee Performance". (Case Study at PT. Bank Artha Grahainternational Tbk, Manado Branch Calaca). Jurnal Berkala Ilmiah Efisiensi. Volume 15 No. 05 Tahun 2015. Hal. 818-827.

Flippo , Edwin B. 2013. Personel Management (Manajemen Personalia), Edisi. VII, Terjemahan Alponso S. Jakarta: Erlangga.

Gibson, M. 2010. Manajemen Sumber Daya Manusia. Cetakan ke dua. Jakarta: Erlangga. 
Hasibuan, Malayu S.P. 2017. Manajemen Sumber Daya Manusia. Jakarta: PT. Bumi Aksara.

Heruwanto, Joni., Septian, Dede dan Kurniawan, Ergo Nurpatria. 2018. "Pengaruh Motivasi dan Lingkungan Kerja Terhadap Kinerja Karyawan PT. Putra Taro Paloma Bogor". Jurnal Manajemen Kewirausahaan. Vol. 15 No. 02 Desember 2018. Hal. 171-182. PISSN: 1858-1048; e-ISSN: 26549247.

Ilyas, Yaslis. 2012. Kinerja, Teori, Penilaian dan Penelitian. Jakarta: Pusat Kajian Ekonomi Kesehatan FKM Universitas Indonesia.

Mangkunegara, Anwar Prabu. 2017. Manajemen Sumber Daya Manusia Perusahaan, Cetakan Kesepuluh, Bandung: PT. Remaja Rosdakarya.

Mathis, Robert L. dan John H. Jackson. 2012. Manajemen Sumber Daya Manusia. Edisi Pertama. Jakarta: Salemba Empat.

Nitisemito, Alex S. 2010. Manajemen dan Sumber Daya Manusia. BPFE UGM, Yogyakarta.

Riduwan dan Sunarto. 2013. Pengantar Statistika: Untuk Penelitian Pendidikan, Sosial, Ekonomi, Komunikasi, dan Bisnis. Bandung: Alfabeta
Robbins, Stephen P. 2015. Perilaku Organisasi. Jakarta: Salemba Empat.

Rusmawita. 2016. "Pengaruh Motivasi dan Lingkungan Kerja Terhadap Kinerja Pegawai Dinas Perkebunan Kabupaten Mamuju Utara". Jurnal Katalogis, Volume 4 Nomor 5, Mei 2016. Hal. 121-127. ISSN: 23022019.

Sedarmayanti. 2017. Manajemen Sumber Daya Manusia. Bandung: PT. Refika Aditama.

Siagian, Sondang P. 2014. Manajemen Sumber Daya Manusia. Jakarta: Bumi Aksara.

Simanjuntak, Payaman J. 2011. Manajemen Evaluasi Kinerja. Edisi 3. Jakarta: Fakultas UI

Sugiyono. 2018. Statikstika Untuk Penelitian. Bandung: Alfabeta.

Sutrisno, Edy 2016, Manajemen Sumber Daya Manusia, Cetakan Kedelapan, Jakarta: Prenamedia Group.

Uno, Hamzah B. M. 2011. Teori Motivasi dan Pengukurannya. Jakarta: PT Bumi Aksara.

Peraturan Pemerintah Nomor 06 Tahun 2010 tentang Polisi Pamong Praja

Undang-Undang Nomor 32 Tahun 2004 tentang Pemerintah Daerah

Kep. Menteri Dalam Negeri Nomor: UR 32/2/21 tentang Perubahan Nama Detasemen Polisi Pamong Praja 